\title{
Bacterial Communities in the Rhizosphere of Amilaceous Maize (Zea mays L.) as Assessed by Pyrosequencing
}

\author{
David Correa-Galeote ${ }^{1 *}$, Eulogio J. Bedmar ${ }^{*}$, Antonio J. Fernández-González", \\ Manuel Fernández-López ${ }^{1}$ and Gregorio J. Arone ${ }^{2}$
}

1 Department of Soil Microbiology and Symbiotic Systems, Estación Experimental del Zaidín, Agencia Estatal Consejo Superior de Investigaciones Cientificas, Granada, Spain, ${ }^{2}$ Department of Agricultural Sciences, National University of Huancavelica, Huancavelica, Peru

\section{OPEN ACCESS}

Edited by:

Antonio M. De Ron,

Spanish National Research Council,

Spain

Reviewed by:

Birgit Mitter,

Austrian Institute of Technology,

Austria

Christel Baum,

University of Rostock, Germany

Diego Flores,

Colegio de Postgraduados, Mexico

*Correspondence:

David Correa-Galeote david.correa@eez.csic.es

Eulogio J. Bedmar

eulogio.bedmar@eez.csic.es

Specialty section:

This article was submitted to Crop Science and Horticulture,

a section of the journal

Frontiers in Plant Science

Received: 29 April 2016

Accepted: 27 June 2016

Published: 29 July 2016

Citation:

Correa-Galeote D, Bedmar EJ,

Fernández-González AJ,

Fernández-López M and Arone Gu

(2016) Bacterial Communities

in the Rhizosphere of Amilaceous

Maize (Zea mays L.) as Assessed by

Pyrosequencing.

Front. Plant Sci. 7:1016

doi: 10.3389/fpls.2016.01016
Maize (Zea mays L.) is the staple diet of the native peasants in the Quechua region of the Peruvian Andes who continue growing it in small plots called chacras following ancestral traditions. The abundance and structure of bacterial communities associated with the roots of amilaceous maize has not been studied in Andean chacras. Accordingly, the main objective of this study was to describe the rhizospheric bacterial diversity of amilaceous maize grown either in the presence or the absence of bur clover cultivated in soils from the Quechua maize belt. Three 16S rRNA gene libraries, one corresponding to sequences of bacteria from bulk soil of a chacra maintained under fallow conditions, the second from the rhizosphere of maize-cultivated soils, and the third prepared from rhizospheric soil of maize cultivated in intercropping with bur clover were examined using pyrosequencing tags spanning the V4 and V5 hypervariable regions of the gene. A total of 26031 sequences were found that grouped into 5955 distinct operational taxonomic units which distributed in 309 genera. The numbers of OTUs in the libraries from the maize-cultivated soils were significantly higher than those found in the libraries from bulk soil. One hundred ninety seven genera were found in the bulk soil library and 234 and 203 were in those from the maize and maize/bur clover-cultivated soils. Sixteen out of the 309 genera had a relative abundance higher than $0.5 \%$ and the were (in decreasing order of abundance) Gp4, Gp6, Flavobacterium, Subdivision3 genera incertae sedis of the Verrucomicrobia phylum, Gemmatimonas, Dechloromonas, Ohtaekwangia, Rhodoferax, Gaiella, Opitutus, Gp7, Spartobacteria genera incertae sedis, Terrimonas, Gp5, Steroidobacter and Parcubacteria genera incertae sedis. Genera Gp4 and Gp6 of the Acidobacteria, Gemmatimonas and Rhodoferax were the most abundant in bulk soil, whereas Flavobacterium, Dechloromonas and Ohtaekwangia were the main genera in the rhizosphere of maize intercropped with bur clover, and Gp4, Subdivision3 genera incertae sedis of phylum Verrucomicrobia, Gp6 and Rhodoferax were the main genera in the rhizosphere of maize plants. Taken together, our results suggest that bur clover produces specific changes in rhizospheric bacterial diversity of amilaceous maize plants.

Keywords: maize rhizospheric soil, bacterial community, pyrosequncing, 16S rRNA gene, Andean chacras 


\section{INTRODUCTION}

Maize (Zea mays L.) reached the southern Andean highlands after its domestication in Mexico some 8700 years before the present (Piperno et al., 2009; van Heerwaarden et al., 2011; Grobman et al., 2012), and is since then the staple diet of the Quechua natives. Despite 500 years of Western colonization and national modernization efforts, native peasants continue growing amilaceous maize as did their ancestors, mostly without chemical fertilization and no irrigation. Most farmers (94.3\%) do not use certified seeds because the fields are planted with their own community seeds (Instituto Nacional de Estadística e Informática [INEI], 2012), which include more than 1600 entries grouped in 55 races (Manrique, 1997).

It is well established that, in addition to mineral fertilizers, which are not usually employed in the Quechua agricultural practices, $\mathrm{N}$ inputs to agriculture can be obtained from symbiotic nitrogen fixation by rhizobial bacteria inside root nodules of leguminous plants (Sprent, 2009), and that rhizobia associated with feed/fodder legumes contribute a substantial proportion of this fixed nitrogen (Herridge et al., 2008). In the traditional Quechua farming, amilaceous maize seeds are used for sowing at each growing season and plants grow associated with innately emerged bur clover (Medicago hispida, Gaernt. syn. M. polymorpha L.), an annual shrub of the Fabaceae family within the tribe Trifolieae which, though native to the Mediterranean basin, is distributed worldwide. In the Peruvian Andes bur clover grows up to almost $4000 \mathrm{~m}$ above sea level where it is also widely used as a pasture and as a cover crop, greatly contributing to the fodder units required for feeding of the national cattle. The microsymbiont from nodules of bur clover has been isolated and identified as Ensifer medicae, and the rhizobial-M. hispida symbiotic association has been suggested to be the main $\mathrm{N}$ source for growth of maize plants in the Andean chacras (Arone et al., 2014).

The plant rhizosphere is a complex environment where soil microbial communities play a key role in ecosystems functions and are among the most complex, diverse and important assemblages in the biosphere. Accordingly, the study of plant-associated microorganisms is of great interest for their contribution to plant nutrition, hormonal control of plant growth, disease suppression, etc. (Bastida et al., 2009). Many studies on the composition and community structure of plant rhizosphere have been performed by using culturedependent techniques and low-resolution molecular methods such as DGGE, TGGE, PLFA and SSCP profiles of microbial communities. Although isolation of culturable bacteria is appropriate for functional analysis, this approach often shows a rather limited diversity because a high percentage of naturally occurring bacteria remains in a non-culturable state (Oliver, 2000; Torsvik et al., 2002). Culture-independent molecular methods provide additional information on the diversity of bacterial communities by analyzing and comparing a very large number of samples. Among them, the bar-coded pyrosequencing technology introduced by 454 Life Science (Margulies et al., 2005; Rothberg and Leamon, 2008) describes microbial community composition in complex habitats such as the deep sea (Sogin et al., 2006; Huse et al., 2008; Polymenakou et al., 2015), human microbiome (Sundquist et al., 2007; Dethlefsen et al., 2008; Claesson et al., 2009; Hang et al., 2014), coastal microbial mats (Bolhuis and Stal, 2011; Tytgat et al., 2014) and dental implants (Kumar et al., 2012; Dabdoub et al., 2013), and soil (Uroz et al., 2010; Mao et al., 2011; Barberán et al., 2012; Sun et al., 2014; Sengupta and Dick, 2015).

Previous studies have analyzed bacterial taxa associated with maize. Some of these studies have been focused on the culturable fraction (Rai et al., 2007; Rijavec et al., 2007; Pereira et al., 2009) and others have assessed bacterial diversity independently of culture (Schmalenberger and Tebbe, 2003; Herschkovitz et al., 2005a,b; Sanguin et al., 2006a,b; Pereira et al., 2011; Ikeda et al., 2013). New generation sequencing has also been used to analyze the diversity and heritability of the maize rhizosphere microbiome under field conditions (Peiffer et al., 2013) and the importance of rare taxa for bacterial diversity in the rizosphere of Bt- and conventional maize varieties (Dohrmann et al., 2013). Because bacterial diversity in roots of amilaceous maize grown in Andean chacras has not been studied using high throughput sequencing, the main objective of this work was to describe the abundance and structure of bacterial communities associated with the roots of amilaceous maize by pyrosequencing. Given that amilaceous maize grows together with bur clover, we hypothesized that plant cultivation type could affect abundance and composition of maize rhizospheric bacteria. To test this hypothesis, we have analyzed changes on rhizospheric bacterial diversity in the absence and the presence of bur clover.

\section{MATERIALS AND METHODS}

\section{Site Description and Soil Sampling}

Chacras are small parcels of soil $\left(200-10000 \mathrm{~m}^{2}\right)$ used by Quechua peasants to grow maize, quinoa, wheat, potatoes, and others cereals and vegetables. Soils were taken from three chacras within the same soil plot located near Allpas $\left(12^{\circ} 50^{\prime} 27^{\prime \prime} \mathrm{S}\right.$, $74^{\circ} 34^{\prime} 14^{\prime \prime} \mathrm{W}$, at $3537 \mathrm{~m}$ above sea level), a village in the province of Acobamba (Huancavelica, Peru). At sampling time, one chacra had been cultivated with amilaceous maize (M soil) for 3 years, other with maize and bur clover (MT soil) for 5 years, and the third was bulk soil from a chacra under fallow conditions (B soil) for at least 3 years. Seeds of $Z$. mays $\mathrm{L}$. morphotype Qarway were planted by mid October 2012 and soil samples collected 120 days later, when the plants were at the grain filling stage. At the second hilling stage, 75-90 days after planting, bur clover looms up without previous sowing and has to be removed by hand to maintain the chacras free of the legume. Lateral roots ( $\sim 2 \mathrm{~mm}$ diameter, $2-3 \mathrm{~cm}$ long; $5-10 \mathrm{~cm}$ depth) were taken from maize plants grown at four different sites within each chacra and four replicates were sampled for each site. After cleaning of the soil attached to the roots, the remaining adhering rhizospheric soil was carefully removed and pooled together to obtain $2 \mathrm{~g}$. Bulk soil samples (four sites, four replicates/site; $0-5 \mathrm{~cm}$ depth) were taken from the chacra under fallow conditions. Soil samples were kept at $-20^{\circ} \mathrm{C}$ until further processing. The three chacras belong to the same soil plot, which 
has a sandy-loam texture (62.5\% sand, $30.0 \%$ silt, $7.5 \%$ clay); the average $\mathrm{pH}$ was 6.3 and that of the soil organic matter was $28.7 \mathrm{~g} / \mathrm{soil} \mathrm{kg}$.

\section{Extraction of DNA from Soil}

DNA was extracted from $250 \mathrm{mg}$ of unfrozen soil as previously indicated (Correa-Galeote et al., 2013). Essentially, samples were homogenized in $1 \mathrm{ml}$ of extraction buffer containing 100 mM Tris (pH 8.0), 100 mM EDTA, $100 \mathrm{mM} \mathrm{NaCl}, 1 \%$ $(\mathrm{w} / \mathrm{v})$ polyvinylpyrrolidone and $2 \%(\mathrm{w} / \mathrm{v})$ sodium dodecyl sulfate using a 2-ml mini-bead-beater tube containing $0.5 \mathrm{~g}$ and $0.1 \mathrm{~g}$ of $106-\mu \mathrm{m}$ - and 2-mm-diameter glass beads, respectively, for $60 \mathrm{~s}$ at $1600 \mathrm{rpm}$. Cell debris was eliminated by centrifugation (14000 rpm for $5 \mathrm{~min}$ at $4^{\circ} \mathrm{C}$ ). Proteins were removed by treatment with $5 \mathrm{M}$ sodium acetate. After treatment for $12 \mathrm{~h}$ with ice-cold isopropanol, nucleic acids were precipitated by centrifugation ( $14000 \mathrm{rpm}$ for $30 \mathrm{~min}$ at $4^{\circ} \mathrm{C}$ ), washed with $70 \%$ ice-cold ethanol, recentrifruged (14000 rpm for $15 \mathrm{~min}$ at $4^{\circ} \mathrm{C}$ ) and air-dried for $30 \mathrm{~min}$. Finally, DNA was purified using GeneClean columns (Qiagen). Quality and size of DNA were checked by electrophoresis on $1 \%$ agarose and quantified by spectrophotometry at $260 \mathrm{~nm}$ using a Nanodrop spectrophotometer (NanoDrop ND1000).

\section{Amplification and Pyrosequencing of DNA from Maize Roots}

Polymerase chain reaction (PCR) amplification of the hypervariable V4-V5 regions of the 16S rRNA gene was performed over each individual DNA extraction from soils using universal primers U519F and U926R (Baker et al., 2003) joined to a multiplex identifier sequence (Binladen et al., 2007; Parameswaran et al., 2007). For each sample, amplicons were generated in several replicate PCRs using mixtures $(25 \mu \mathrm{l})$ that contained 25 pmol of each primer, $1.8 \mathrm{mM} \mathrm{MgCl}_{2}, 0.2 \mathrm{mM}$ dNTPs, $1 \times$ the corresponding Taq buffer, $1 \mathrm{U}$ of Taq Master (5 Prime, USA) and $10 \mathrm{ng}$ of the DNA template. The PCR program consisted of an initial denaturation step at $94^{\circ} \mathrm{C}$ for $4 \mathrm{~min}, 25$ cycles of denaturation at $94^{\circ} \mathrm{C}$ for $15 \mathrm{~s}$, primer annealing at $55^{\circ} \mathrm{C}$ for $45 \mathrm{~s}$ and extension at $72^{\circ} \mathrm{C}$ for $1 \mathrm{~min}$, followed by a final step of heating at $72^{\circ} \mathrm{C}$ for $10 \mathrm{~min}$. Amplicons of the same treatment were pooled to reduce per-PCR variability and purified using the ultracentrifugal filters Ultracel-100 K membranes (Amicon) according to the manufacturer's instructions. After quantification by Nanodrop ND1000 and visualization of the DNA by agarose electrophoresis, the samples were combined in equimolar amounts and pyrosequenced in a Roche Genome Sequencer FLX system using 454 Titanium chemistry at LifeSequencing S.L. (Valencia, Spain).

\section{Taxonomic Assignment of Sequence Reads and Diversity Indexes}

Raw sequences were processed through the Ribosomal Database Project (RDP) pyrosequencing pipeline ${ }^{1}$ release 11 (Cole et al., 2014). Sequences were trimmed for primers, filtered and assigned

${ }^{1}$ http://pyro.cme.msu.edu to three libraries (BG, MG and MTG containing 16S rRNA gene sequences from $\mathrm{B}, \mathrm{M}$ and $\mathrm{MT}$ soils, respectively) according to their tags. Sequences shorter than 150 base pair, with quality scores $<20$ or containing any unresolved nucleotides were removed from the dataset. Chimeras were identified using the Uchime tool from FunGene database (Edgar et al., 2011) and removed from the dataset. Sequences were aligned using the Infernal alignment tool in RDP (Nawrocki et al., 2009). Aligned sequences were clustered into operational taxonomic units (OTUs) defined at 97\% similarity cutoff using Complete Linkage Clustering RDP tool and their relative abundances calculated. The number of sequences in each OTU was employed to calculate the Good's coverage index, which is considered a relative measure of how well the sequences obtained represent the entire populations (Hughes and Bohannan, 2004). The RDP Classifier, a Bayesian rRNA classifying algorithm (Wang et al., 2007), was used to assign phylogenetic groups based on sequence similarity. Matches with an RDP confidence estimate below $60 \%$ were designated as unclassified bacteria. Shannon $\left(\mathrm{H}^{\prime}\right)$ and Simpson $\left(\mathrm{S}^{\prime}\right)$ diversity indexes and Jaccard indexes $\left(J_{\text {class }}\right.$ and $J_{\text {abund }}$ ) were used to analyze the alpha- and beta-diversity, respectively (Chao et al., 2005).

\section{Statistical Analyses}

Relative abundances of the main genera were compared using the $G$-test (w/Yates') + Fischer's test in the STAMP software (Parks et al., 2014). Comparisons among the total number of sequences in the genomic libraries were done using the Newcombe-Wilson method (Newcombe, 1998; Parks and Beiko, 2010).

\section{Accession Numbers}

Pyrosequencing reads have been sent to GenBank to obtain their under accession numbers. They are available as KX479121KX485313, KX559454-KX570596 and KX470813-KX479120 for the genomic libraries MTG, MG and BG, respectively.

\section{RESULTS}

\section{Pyrosequencing and Sequence Analysis}

A total of 38786 sequences were obtained from the three 16S rDNA samples sent to pyrosequencing, of which 26031 were retained after filtering and removing chimeras. The mean number of total retained sequences per library was 8677 , ranging from 6286 to 11387 . Average length of retained sequences was

TABLE 1 | Number of OTUs, values of Good's coverage index, and Shannon and Simpson biodiversity indexes in genomic libraries from bulk soil (BG) and rhizospheric soil of maize (MG) and maize intercropped with clover (MTG) grown in Andean chacras.

\begin{tabular}{lccc}
\hline Diversity index & MTG & MG & BG \\
\hline Number of OTUs & 1846 & 3287 & 2318 \\
Good's coverage & 85.58 & 84.92 & 86.44 \\
Shannon & 6.55 & 7.21 & 7.06 \\
Simpson & 0.0056 & 0.0031 & 0.0016
\end{tabular}


TABLE 2 | Number of taxa and of 16S rRNA sequences in genomic libraries from bulk soil (BG) and rhizospheric soil of maize (MG) and maize intercropped with clover (MTG) grown in Andean chacras.

\begin{tabular}{|c|c|c|c|c|c|c|}
\hline & \multicolumn{6}{|c|}{ Genomic Libraries } \\
\hline & \multicolumn{2}{|c|}{ MTG } & \multicolumn{2}{|c|}{ MG } & \multicolumn{2}{|c|}{ BG } \\
\hline & Number of taxa & $\begin{array}{c}\text { Number of } \\
\text { sequences (\%) }\end{array}$ & Number of taxa & $\begin{array}{c}\text { Number of } \\
\text { sequences (\%) }\end{array}$ & Number of taxa & $\begin{array}{c}\text { Number of } \\
\text { sequences (\%) }\end{array}$ \\
\hline Phylum & 21 & 5711 (90.85) & 23 & $9594(84.26)$ & 21 & $6898(82.53)$ \\
\hline Class & 41 & 5066 (80.59) & 44 & 8390 (73.68) & 42 & 8358 (75.93) \\
\hline Order & 43 & 3933 (62.57) & 51 & $5136(45.10)$ & 45 & 3391 (39.97) \\
\hline Family & 43 & 3607 (57.38) & 51 & $4141(36.37)$ & 45 & 2620 (31.35) \\
\hline Genus & 203 & $3131(49.81)$ & 234 & $5650(49.62)$ & 197 & $4003(47.89)$ \\
\hline Unclassified sequences & & 575 (9.15) & & $1793(15.75)$ & & $1460(17.47)$ \\
\hline
\end{tabular}

The percentage of sequences in relation with the total number of sequences is shown in brackets.

$374 \pm 5$ base pair (mean \pm SD). All the sequences aligned correctly in the expected position of the 16S rDNA sequence of Escherichia coli and were grouped at 97\% similarity in 5955 distinct OTUs, of which 1846, 3287 and 2318 were found in MTG, MG and BG libraries, respectively (Table 1), which also contained 575 (9.15\%), 1793 (15.75\%), and 1460 (17.47\%) unclassified sequences, respectively (Table 2; Figure 1). The remaining valid sequences distributed into 21,23 , and 21 phyla, respectively (Table 2 ), of which phyla Proteobacteria, Bacteroidetes, Acidobacteria, Actinobacteria, Firmicutes, Verrucomicrobia, Gemmatimonadetes, Planctomycetes, Chloroflexi, Armatimonadetes, Parcubacteria, Nitrospirae, Candidatus Saccharibacteria, candidate division WPS2, candidate division WPS-1, Latescibacteria, BRC1 and Microgenomates (in decreasing abundance) were found in all the three libraries (Figure 1). Phyla Spirochaetes and Chlamydiae were found in MTG and MG and so were Ignavibacteriae and Cyanobacteria in libraries MG and BG, respectively (Figure 1). Hydrogenedentes was detected only in MTG, DeinococcusThermus in MG and Elusimicrobia in BG (Figure 1). Numbers of classes, orders, families and genera are also shown in Table 2.

\section{Coverage and Diversity Indexes}

With values of the Good's coverage index higher than $80 \%$ at 90\% confidence interval (Table 1), the Shannon index of 5.13 for OTUs in the MTG clone library was lower than those of 7.06 and 7.21 for the FG and MG libraries, respectively. The Simpson index, however, showed clear differences among the OTUs in each library, with values of $0.0016,0.0031$ and 0.0056 for the MTG, MG and BG clone libraries, respectively (Table 1).

Sequences in library BG distributed in 197 genera, a value lower than those of 203 and 234 found in libraries MTG and MG, respectively (Table 2). Of the total number of genera, the BG library shared 132 and 155 with the MTG and MG libraries, respectively, and libraries MTG and MG had 159 genera in common (Table 3). Values of the $J_{\text {class }}$ index were similar between the BG and MG libraries (0.56) and the MTR and MG libraries (0.57), values that were higher than that (0.49) between the MTG and BG libraries (Table 3). The $J_{\text {abund }}$ indexes for the multiple comparisons among genomic libraries were similar (Table 3 ).

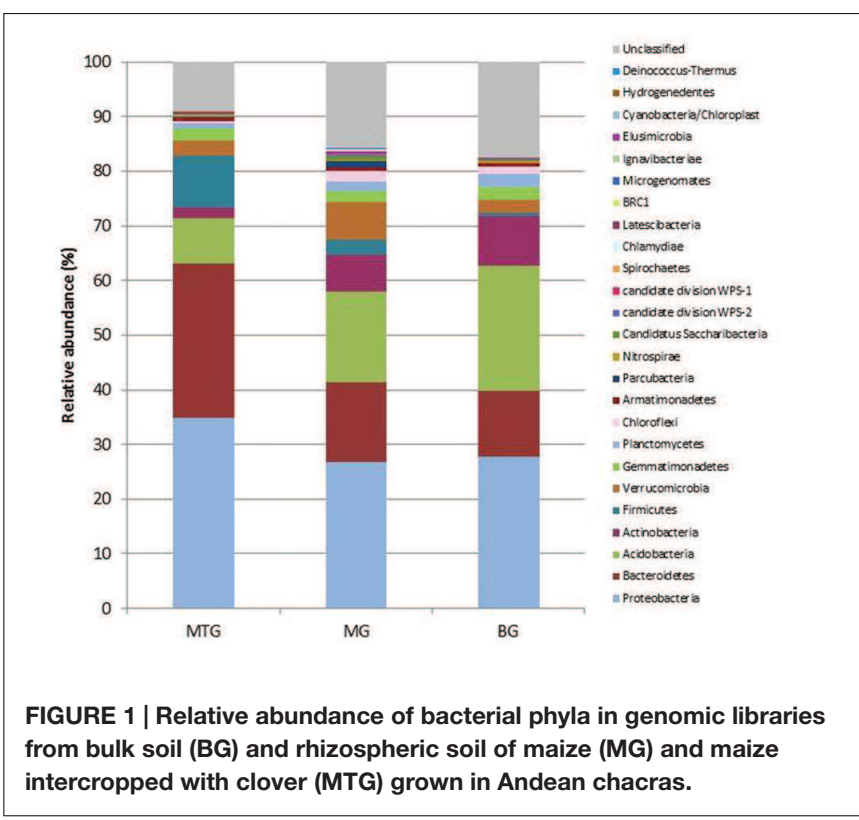

TABLE 3 | Number of shared genera among genomic libraries, and Jaccard similarity indexes using presence/absence $\left(J_{\text {class }}\right)$ and relative abundances $\left(J_{\text {abund }}\right.$ ) of the genera in libraries from bulk soil (BG) and rhizospheric soil of maize (MG) and maize intercropped with clover (MTG) grown in Andean chacras.

\begin{tabular}{lccc}
\hline & Number of shared genera & $\boldsymbol{J}_{\text {class }}$ & $\boldsymbol{J}_{\text {abund }}$ \\
\hline MTG-BG & 132 & 0.49 & 0.94 \\
MG-BG & 155 & 0.56 & 0.92 \\
MTG-MG & 159 & 0.57 & 0.98 \\
\hline
\end{tabular}

\section{Taxonomic Composition and Statistical Analyses}

From the total 26031 sequences, only 12784 could be assigned to 309 different genera (Supplementary Table S1). Sixteen (16) out of the 309 genera had a relative abundance higher than $0.5 \%$, and represented the $64.23 \%$ of the total number of sequences classified at the genus level. Altogether, these genera were (in 


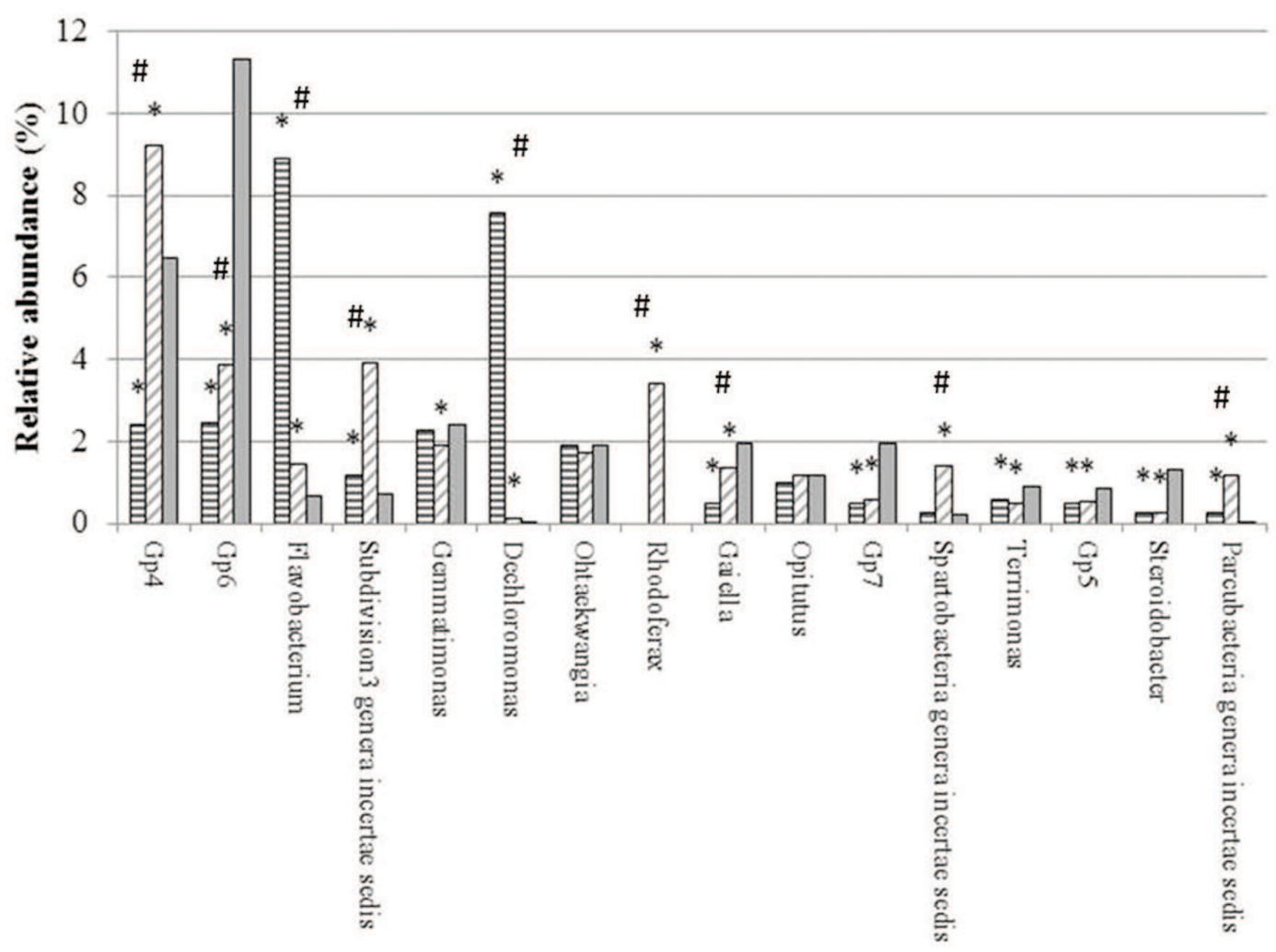

FIGURE 2 | Relative abundance (\%) of main genera in genomic libraries from bulk soil (BG, solid gray) and rhizospheric soil of maize (MG, horizontal gray lines) and maize intercropped with clover (MTG, diagonal gray lines) grown in Andean chacras. Relative abundances were compared using the combined $\mathrm{G}+$ Fischer tests $(\alpha \leq 0.05)$. *indicates statistically differences between the sequences in the MTG and MG libraries as compared to the BG library; \# indicates statistically differences between the sequences in the MTG and MG libraries.

decreasing order of abundance) Gp4, Gp6, Flavobacterium, Subdivision3 genera incertae sedis of the Verrucomicrobia phylum, Gemmatimonas, Dechloromonas, Ohtaekwangia, Rhodoferax, Gaiella, Opitutus, Gp7, Spartobacteria genera incertae sedis, Terrimonas, Gp5, Steroidobacter and Parcubacteria genera incertae sedis (Supplementary Table S1) (Figure 2).

Relative abundances of genera Flavobacterium, Subdivision3 genera incertae sedis of the Verrucomicrobia phylum, Dechloromonas and Parcubacteria in each the MTG and MG libraries were statistically higher than those in the BG library. In contrast, the number of sequences of genera Gp6, Gaiella, Gp7, Terrimonas, Gp5 and Steroidobacter in the MTG and MG libraries were lower than those in the BG library.

Numbers of sequences of genera Flavobacterium and Dechloromonas in the MTG library were statistically higher than those in the MG library (Figure 2). On the other hand, the relative abundance of genera Gp4, Gp6, Subdivision3 genera incertae sedis of phylum Verrucomicrobia, Rhodoferax, Gaiella and Spartobacteria in MTG were significantly lower than those in the MG library (Figure 2). Differences in the relative abundance of sequences corresponding to genera Gemmatimonas, Ohtaekwangia, Opitutus, Gp7, Terrimonas, Gp5,
Steroidobacter and Parcubacteria were not found between the MTG and MG libraries (Figure 2).

\section{DISCUSSION}

Using 454 next generation sequencing we assessed the composition and abundance of bacterial rhizospheric communities of amilaceous maize plants grown in Andean chacras following Quechua traditional practices. The total number of genera found in our genomic libraries were higher than those obtained in previous studies based on culturedependent and culture-independent methods (Gomes et al., 2001; Schmalenberger and Tebbe, 2002; Baumgarte and Tebbe, 2005; Brusetti et al., 2005; Aira et al., 2010; Miethling-Graff et al., 2010; Pereira et al., 2011; García-Salamanca et al., 2013; Li et al., 2014), and similar to those found in the rhizosphere of different maize varieties after pyrosequencing (Dohrmann et al., 2013).

Altogether, a $12.71 \%$ of the total sequences found inside roots corresponded to unclassified bacteria, which indicates the presence of hitherto uncultured bacterial groups. A high percentage of unclassified sequences have also been reported in the rhizosphere of maize plants when pyrosequencing was used to study bacterial biodiversity (Dohrmann et al., 2013). 
A variety of bacteria have been reported to be rhizospheric, among them mostly Proteobacteria, Firmicutes, Actinobacteria, Acidobacteria and Bacteroidetes (Sharma et al., 2005; DeAngelis et al., 2009; Peiffer et al., 2013; Uroz et al., 2013). In our study, regardless of soil provenance, members of phylum Proteobacteria were the most abundant (29.10\%) followed by those of Bacteroidetes (17.03\%), Acidobacteria (16.62\%), Actinobacteria (6.40\%), Verrucomicrobia (4.48\%) and Firmicutes (3.55\%) (Figure 1). Although the amount of bacterial phyla found in the three genomic libraries was similar (Table 2), the number of OTUs and values of the Shannon and Simpson indexes for the MTG library were lower than those for the BG library (Table 1), which suggests that intercropping reduced richness of the community. These results agree with those previously published that show that microbial diversity in maize rhizospheric soils was lower than in bulk soils (GarcíaSalamanca et al., 2013; Peiffer et al., 2013). This reduction can be explained if one considers that maize plants intercropped with bur clover somehow select from the bulk soil those bacteria able to promote plant growth and development; e.g., due to the symbiosis with E. medicae (Arone et al., 2014) free-living $N_{2}$ bacteria would not be required for plant growth. Our results also show that diversity in the MG library was higher than that in the BG library (Table 1). It is possible that the absence of bur clover promts the plants to increase bacterial diversity around the roots to improve their nutrition. Alternatively, it is also possible that more time is required for the maize crop to become well established in soils, which, in turn, could alter the soil microbiota. On the other hand, clear dominance of specific rhizospheric bacteria was not found, and multiple comparisons analyses of the values of the $\beta$-diversity indexes indicated the three genomic libraries have a similar bacterial community core. The absence of specific phylogenetic groups between bulk and rhizospheric soil from an oak forest after pyrosequencing of the 16S rRNA gene has been reported (Uroz et al., 2010).

Plants influence the abundance and composition of the bacterial rhizospheric community by secreting a variety of compounds through their roots into the surrounding soil to feed and manipulate the microbes that live there (Johnston-Monje et al., 2016). If one considers the bulk soil of the chacras as the reservoir of microbial communities, whereas maize increased relative abundance of genera Gp4, Flavobacterium, Subdivision3 genera incertae sedis of the Verrucomicrobia phylum, Dechloromonas, Rhodoferax, Spartobacteria and Parcubacteria

\section{REFERENCES}

Aira, M., Gómez-Brandón, M., Lazcano, C., Bååth, E., and Domínguez, J. (2010). Plant genotype strongly modifies the structure and growth of maize rhizosphere microbial communities. Soil Biol. Biochem. 42, 2276-2281. doi: 10.1016/j.soilbio.2010. 08.029

Arone, G., Calderón, C., Moreno, S., and Bedmar, E. J. (2014). Identification of Ensifer strains isolated from root nodules of Medicago hispida grown in association with Zea mays in the Quechua region of the Peruvian Andes. Biol. Fertil. Soils 50, 185-190. doi: 10.1007/s00374-0130825-3 incertae sedis, the maize-bur clover consortium increased relative abundance of Flavobacterium, Subdivision3 genera incertae sedis of the Verrucomicrobia phylum, Dechloromonas and Parcubacteria incertae sedis.

It is well established that plant genotype plays a significant role in shaping plant-associated microbial communities and in determining the biological outcome of such associations (Smith and Goodman, 1999; Ding et al., 2013). In this sense, 16S rRNA-based pyrosequencing studies on microbial diversity from rhizosphere of different maize genotypes have shown that variation in microbial diversity could be attributed to host genetics (Bouffaud et al., 2012; Peiffer et al., 2013). Because seeds of amilaceous maize used for planting were the same and the environmental conditions (including soil type and physicochemical properties), were, also, the same for the three chacras, our results suggest that the plant could be a main factor controlling bacterial diversity in their rhizosphere, whether alone (maize) or in consortium with other plants (maize and bur clover). Since richness of bacteria colonizing maize roots was based on pyrosequencing, it is not known whether the detection of bacteria based on DNA signature alone represent active microbes that are interacting with the host plant.

\section{AUTHOR CONTRIBUTIONS}

Conceived and designed the experiments: DC-G, EJB, GJA. Performed the experiments: DC-G, GJA. Analyzed the data: DC-G, EJB. Contributed reagents/materials/analysis tools: AJF-G, MF-L. Improve the paper: AJF-G, MF-L, GJA. Wrote the paper: DC-G, EJB.

\section{ACKNOWLEDGMENTS}

This study was supported by ERDF-cofinanced grant PE2012AGR1968 from Consejería de Economía, Innovación y Ciencia (Junta de Andalucía, Spain) and the CSIC-sponsored I-COOP Agrofood project 2014CD0013.

\section{SUPPLEMENTARY MATERIAL}

The Supplementary Material for this article can be found online at: http://journal.frontiersin.org/article/10.3389/fpls.2016.01016

Baker, G. C., Smith, J. J., and Cowan, D. A. (2003). Review and re-analysis of domain-specific $16 \mathrm{~S}$ primers. J. Microbiol. Methods 55, 541-555. doi: 10.1016/j.mimet.2003.08.009

Barberán, A., Bates, S. T., Casamayor, E. O., and Fierer, N. (2012). Using network analysis to explore co-occurrence patterns in soil microbial communities. ISME J. 6, 343-351. doi: 10.1038/ismej.2011.119

Bastida, F., Moreno, J. L., Nicolás, C., Hernández, T., and García, C. (2009). Soil metaproteomics: a review of an emerging environmental science. Significance, methodology and perspectives. Eur. J. Soil Sci. 60, 845-859. doi: 10.1111/j.15746941.2011.01284.x

Baumgarte, S., and Tebbe, C. C. (2005). Field studies on the environmental fate of the Cry1 Ab Bt-toxin produced by transgenic maize (MON810) and its effect on 
bacterial communities in the maize rhizosphere. Mol. Ecol. 14, 2539-2551. doi: 10.1111/j.1365-294X.2005.02592.x

Binladen, J., Gilbert, M. T., Bollback, J. P., Panitz, F., Bendixen, C., Nielsen, R., et al. (2007). The use of coded PCR primers enables high-throughput sequencing of multiple homolog amplification products by 454 parallel sequencing. PLoS ONE 2:e197. doi: 10.1371/journal.pone.0000197

Bolhuis, H., and Stal, L. J. (2011). Analysis of bacterial and archaeal diversity in coastal microbial mats using massive parallel 16S rRNA gene tag sequencing. ISME J. 5, 1701-1712. doi: 10.1038/ismej.2011.52

Bouffaud, M.-L., Kyselková, M., Gouesnard, B., Grundmann, G., Muller, D., and Moënne-Loccoz, Y. (2012). Is diversification history of maize influencing selection of soil bacteria by roots? Mol. Ecol. 21, 195-206. doi: 10.1111/j.1365294X.2011.05359.x

Brusetti, L., Francia, P., Bertolini, C., Pagliuca, A., Borin, S., Sorlini, C., et al. (2005). Bacterial communities associated with the rhizosphere of transgenic Bt 176 maize (Zea mays) and its non transgenic counterpart. Plant Soil 226, 11-21. doi: 10.1007/s11104-005-5399-x

Chao, A., Chazdon, R. L., Colwell, R. K., and Shen, T. J. (2005). A new statistical approach for assessing similarity of species composition with incidence and abundance data. Ecol. Lett. 8, 148-159. doi: 10.1111/j.1461-0248.2004.00707.x

Claesson, M. J., O'Sullivan, O., Wang, Q., Nikkilä, J., Marchesi, J. R., Smidt, H., et al. (2009). Comparative analysis of pyrosequencing and a phylogenetic microarray for exploring microbial community structures in the human distal intestine. PLoS ONE 4:e6669. doi: 10.1371/journal.pone.0006669

Cole, J. R., Wang, Q., Fish, J. A., Chai, B., McGarrell, D. M., Sun, Y., et al. (2014). Ribosomal database project: data and tools for high throughput rRNA analysis. Nucleic Acids Res. 42, D633-D642. doi: 10.1093/nar/gkt1244

Correa-Galeote, D., Tortosa, G., and Bedmar, E. J. (2013). Determination of denitrification genes abundance in environmental samples. Metagenomics 2, 235702. doi: $10.4303 / \mathrm{mg} / 235702$

Dabdoub, S., Tsigarida, A. A., and Kumar, P. S. (2013). Patient-specific analysis of periodontal and peri-implant microbiomes. J. Dent. Res. 92, 168S-175S. doi: $10.1177 / 0022034513504950$

DeAngelis, K. M., Brodie, E. L., DeSantis, T. Z., Andersen, G. L., Lindow, S. E., and Firestone, M. K. (2009). Selective progressive response of soil microbial community to wild oat roots. ISME J. 3, 168-178. doi: 10.1038/ismej.2008.103

Dethlefsen, L., Huse, S., Sogin, M. L., and Relman, D. A. (2008). The pervasive effects of an antibiotic on the human gut microbiota, as revealed by deep 16S rRNA sequencing. PLoS Biol. 6:e280. doi: 10.1371/journal.pbio.00 60280

Ding, T., Palmer, M. W., and Melcher, U. (2013). Community terminal restriction fragment length polymorphisms reveal insights into the diversity and dynamics of leaf endophytic bacteria. BMC Microbiol. 13:1. doi: 10.1186/1471-2180-13-1

Dohrmann, A. B., Küting, M., Jünemann, S., Jaenicke, S., Schlüter, A., and Tebbe, C. C. (2013). Importance of rare taxa for bacterial diversity in the rhizosphere of Bt-and conventional maize varieties. ISME J. 7, 37-49. doi: 10.1038/ismej.2012.77

Edgar, R. C., Haas, B. J., Clemente, J. C., Quince, C., and Knight, R. (2011). UCHIME improves sensitivity and speed of chimera detection. Bioinformatics 27, 2194-2200. doi: 10.1093/bioinformatics/btr381

García-Salamanca, A., Molina-Henares, M. A., Dillewijn, P., Solano, J., PizarroTobías, P., Roca, A., et al. (2013). Bacterial diversity in the rhizosphere of maize and the surrounding carbonate-rich bulk soil. Microb. Biotechnol. 6, 36-44. doi: 10.1111/j.1751-7915.2012.00358.x

Gomes, N. C. M., Heuer, H., Schönfeld, J., Costa, R., Mendonca-Hagler, L., and Smalla, K. (2001). Bacterial diversity of the rhizosphere of maize (Zea mays) grown in tropical soil studied by temperature gradient gel electrophoresis. Plant Soil 232, 167-180. doi: 10.1023/A:1010350406708

Grobman, A., Bonavia, D., Dillehay, T. D., Piperno, D. R., Iriarte, J., and Holst, I. (2012). Preceramic maize from Paredones and Huaca Prieta, Peru. Proc. Natl. Acad. Sci. U.S.A. 109, 1755-1759. doi: 10.1073/pnas.1120270109

Hang, J., Desai, V., Zavaljevski, N., Yang, Y., Lin, X., Satya, R. V., et al. (2014). 16S rRNA gene pyrosequencing of reference and clinical samples and investigation of the temperature stability of microbiome profiles. Microbiome 2, 31. doi: 10.1186/2049-2618-2-31

Herridge, D. F., Peoples, M. B., and Boddey, R. M. (2008). Global inputs of biological nitrogen fixation in agricultural systems. Plant Soil 311, 1-18. doi: 10.1007/s11104-008-9668-3
Herschkovitz, Y., Lerner, A., Davidov, Y., Okon, Y., and Jurkevitch, E. (2005a). Azospirillum brasilense does not affect population structure of specific rhizobacterial communities of inoculated maize (Zea mays). Environ. Microbiol. 7, 1847-1852. doi: 10.1111/j.1462-2920.2005.00926.x

Herschkovitz, Y., Lerner, A., Davidov, Y., Rothballer, M., Hartmann, A., Okon, Y., et al. (2005b). Inoculation with the plant-growth-promoting rhizobacterium Azospirillum brasilense causes little disturbance in the rhizosphere and rhizoplane of maize (Zea mays). Microb. Ecol. 50, 277-288. doi: 10.1007/s00248004-0148-x

Hughes, J. B., and Bohannan, B. J. M. (2004). "Application of ecological diversity statistics in microbial ecology," in Molecular Microbial Ecology Manual, Section 7, eds G. A. Kowalchuk, F. J. de Bruijn, I. M. Head, A. D. Akkermans, and J. D. van Elsas (Berlin: Springer), 3223-3246.

Huse, S. M., Dethlefsen, L., Huber, J. A., Welch, D. M., Relman, D. A., and Sogin, M. L. (2008). Exploring microbial diversity and taxonomy using SSU rRNA hypervariable tag sequencing. PLoS Genet. 4:e1000255. doi: 10.1371/journal.pgen.1000255

Ikeda, A. C., Bassani, L. L., Adamoski, D., Stringari, D., Cordeiro, V. K., Glienke, C., et al. (2013). Morphological and genetic characterization of endophytic bacteria isolated from roots of different maize genotypes. Microb. Ecol. 65, 154-160. doi: 10.1007/s00248-012-0104-0

Instituto Nacional de Estadística e Informática [INEI] (2012). IV Censo Nacional Agropecuario. Perú: Instituto Nacional de Estadística e Informática.

Johnston-Monje, D., Lundberg, D. S., Lazarovits, G., Reis, V. M., and Raizada, M. N. (2016). Bacterial populations in juvenile maize rhizospheres originate from both seed and soil. Plant Soil 1-19. doi: 10.1007/s11104-016-2826-0

Kumar, P. S., Mason, M. R., Brooker, M. R., and O'Brien, K. (2012). Pyrosequencing reveals unique microbial signatures associated with healthy and failing dental implants. J. Clin. Periodontol. 39, 425-433. doi: 10.1111/j.1600051X.2012.01856.X

Li, X., Rui, J., Mao, Y., Yannarell, A., and Mackie, R. (2014). Dynamics of the bacterial community structure in the rhizosphere of a maize cultivar. Soil Biol. Biochem. 68, 392-401. doi: 10.1016/j.soilbio.2013.10.017

Manrique, A. (1997). El maíz en el Perú. $2^{\text {a }}$ Edn. Peru: CONCYTEC.

Mao, Y., Yannarell, A. C., and Mackie, R. I. (2011). Changes in N-transforming archaea and bacteria in soil during the establishment of bioenergy crops. PLoS ONE 6:e24750. doi: 10.1371/journal.pone.0024750

Margulies, M., Egholm, M., Altman, W. E., Attiya, S., Bader, J. S., Bemben, L. A., et al. (2005). Genome sequencing in microfabricated high-density picolitre reactors. Nature $15,376-380$.

Miethling-Graff, R., Dockhorn, S., and Tebbe, C. C. (2010). Release of the recombinant $\mathrm{Cry} 3 \mathrm{Bb} 1$ protein of Bt maize MON88017 into field soil and detection of effects on the diversity of rhizosphere bacteria. Eur. J. Soil Biol. 46, 41-48. doi: 10.1016/j.ejsobi.2009.10.003

Nawrocki, E. P., Kolbe, D. L., and Eddy, S. R. (2009). Infernal 1.0: inference of RNA alignments. Bioinformatics 25, 1335-1337. doi: 10.1093/bioinformatics/btp157

Newcombe, R. G. (1998). Two-sided confidence intervals for the single proportion: comparison of seven methods. Stat. Med. 17, 857-872. doi: 10.1002/(SICI)10970258(19980430)17:8<857::AID-SIM777> 3.0.CO;2-E

Oliver, J. D. (2000). "The public health significance of viable but nonculturable bacteria," in Nonculturable Microorganisms in the Environment, eds R. R. Colwell and D. J. Grimes (Washignton, DC: ASM Press), 277-300.

Parameswaran, P., Jalili, R., Tao, L., Shokralla, S., Gharizadeh, B., Ronaghi, M., et al. (2007). A pyrosequencing-tailored nucleotide barcode design unveils opportunities for large-scale sample multiplexing. Nucleic Acids Res. 3, e130. doi: 10.1093/nar/gkm760

Parks, D. H., and Beiko, R. G. (2010). Identifying biologically relevant differences between metagenomic communities. Bioinformatics 26, 715-721. doi: 10.1093/bioinformatics/btq041

Parks, D. H., Tyson, G. W., Hugenholtz, P., and Beiko, R. G. (2014). STAMP: statistical analysis of taxonomic and functional profiles. Bioinformatics 30, 3123-3124. doi: 10.1093/bioinformatics/btu494

Peiffer, J. A., Spor, A., Koren, O., Jin, Z., Tringe, S. G., Dangl, J. L., et al. (2013). Diversity and heritability of the maize rhizosphere microbiome under field conditions. Proc. Natl. Acad. Sci. U.S.A. 110, 6548-6553. doi: 10.1073/pnas.1302837110

Pereira, C. J., Pereira, E. J. G., Cordeiro, E. M. G., Della Lucia, T. M. C., Tótola, M. R., and Guedes, R. N. C. (2009). Organophosphate resistance in the maize 
weevil Sitophilus zeamais: magnitude and behavior. Crop Protect. 28, 168-173. doi: 10.1016/j.cropro.2008.10.001

Pereira, P., Ibáñez, F., Rosenblueth, M., Etcheverry, M., and Martínez-Romero, E. (2011). Analysis of the bacterial diversity associated with the roots of maize (Zea mays L.) through culture-dependent and culture-independent methods. ISRN Ecol. 2011:938546. doi: 10.5402/2011/938546.

Piperno, D. R., Ranere, A. J., Holst, I., Iriarte, J., and Dickau, R. (2009). Starch grain and phytolith evidence for early ninth millennium BP maize from the Central Balsas River Valley, Mexico. Proc. Natl. Acad. Sci. U.S.A. 106, 5019-5024. doi: 10.1073/pnas. 0812525106

Polymenakou, P. N., Christakis, C. A., Mandalakis, M., and Oulas, A. (2015). Pyrosequencing analysis of microbial communities reveals dominant cosmopolitan phylotypes in deep-sea sediments of the eastern Mediterranean Sea. Res. Microbiol. 166, 448-445. doi: 10.1016/j.resmic.2015. 03.005

Rai, R., Dash, P. K., Prasanna, B. M., and Singh, A. (2007). Endophytic bacterial flora in the stem tissue of a tropical maize (Zea mays L.) genotype: isolation, identification and enumeration. World J. Microbiol. Biotechnol. 23, 853-858. doi: $10.1007 / \mathrm{s} 11274-006-9309-\mathrm{z}$

Rijavec, T., Lapanje, A., Dermastia, M., and Rupnik, M. (2007). Isolation of bacterial endophytes from germinated maize kernels. Can. J. Microbiol. 53, 802-808. doi: 10.1139/W07-048

Rothberg, J. M., and Leamon, J. H. (2008). The development and impact of 454 sequencing. Nat. Biotechnol. 26, 1117-1124. doi: 10.1038/nbt 1485

Sanguin, H., Herrera, A., Oger-Desfeux, C., Dechesne, A., Simonet, P., Navarro, E., et al. (2006a). Development and validation of a prototype 16S rRNA-based taxonomic microarray for Alphaproteobacteria. Environ. Microbiol. 8, 289-307. doi: $10.1111 / j .1462-2920.2005 .00895 . x$

Sanguin, H., Remenant, B., Dechesne, A., Thioulouse, J., Vogel, T. M., Nesme, X., et al. (2006b). Potential of a 16S rRNA-based taxonomic microarray for analyzing the rhizosphere effects of maize on Agrobacterium spp. and bacterial communities. Appl. Environ. Microbiol. 72, 4302-4312. doi: 10.1128/AEM.02686-05

Schmalenberger, A., and Tebbe, C. C. (2002). Bacterial community composition in the rhizosphere of a transgenic, herbicide-resistant maize (Zea mays) and comparison to its non-transgenic cultivar Bosphore. FEMS Microbiol. Ecol. 40, 29-37. doi: 10.1111/j.1574-6941.2002.tb00933.x

Schmalenberger, A., and Tebbe, C. C. (2003). Bacterial diversity in maize rhizospheres: conclusions on the use of genetic profiles based on PCR-amplified partial small subunit rRNA genes in ecological studies. Mol. Ecol. 12, 251-262. doi: 10.1046/j.1365-294X.2003.01716.x

Sengupta, A., and Dick, W. A. (2015). Bacterial community diversity in soil under two tillage practices as determined by pyrosequencing. Microb. Ecol. 70, 853-859. doi: 10.1007/s00248-015-0609-4

Sharma, S., Aneja, M. K., Mayer, J., Munch, J. C., and Schloter, M. (2005). Characterization of bacterial community structure in rhizosphere soil of grain legumes. Microb. Ecol. 49, 407-415. doi: 10.1007/s00248-004$0041-7$
Smith, K. P., and Goodman, R. M. (1999). Host variation for interactions with beneficial plant-associated microbes. Annu. Rev. Phytopathol. 37, 473-491. doi: 10.1146/annurev.phyto.37.1.473

Sogin, M. L., Morrison, H. G., Huber, J. A., Welch, D. M., Huse, S. M., Neal, P. R., et al. (2006). Microbial diversity in the deep sea and the underexplored "rare biosphere". Proc. Natl. Acad. Sci. U.S.A. 103, 12115-12120. doi: $10.1073 /$ pnas. 0605127103

Sprent, J. I. (2009). Legume Nodulation: A Global Perspective. Oxford: WileyBlackwell.

Sun, J., Zhang, Q., Zhou, J., and Wei, Q. (2014). Pyrosequencing technology reveals the impact of different manure doses on the bacterial community in apple rhizosphere soil. Appl. Soil Ecol. 78, 28-36. doi: 10.1016/j.apsoil.2014.02.004

Sundquist, A., Bigdeli, S., Jalili, R., Druzin, M. L., Waller, S., Pullen, K. M., et al. (2007). Bacterial flora-typing with targeted, chip-based pyrosequencing. BMC Microbiol. 7:108. doi: 10.1186/1471-2180-7-108

Torsvik, V., Øvreås, L., and Thingstad, T. F. (2002). Prokaryotic diversitymagnitude, dynamics, and controlling factors. Science 296, 1064-1066. doi: $10.1126 /$ science. 1071698

Tytgat, B., Verleyen, E., Obbels, D., Peeters, K., De Wever, A., D’hondt, S., et al. (2014). Bacterial diversity assessment in Antarctic terrestrial and aquatic microbial mats: a comparison between bidirectional pyrosequencing and cultivation. PLoS ONE 9:e97564. doi: 10.1371/journal.pone.0097564

Uroz, S., Buée, M., Murat, C., Frey-Klett, P., and Martin, F. (2010). Pyrosequencing reveals a contrasted bacterial diversity between oak rhizosphere and surrounding soil. Environ. Microbiol. Rep. 2, 281-288. doi: 10.1111/j.17582229.2009.00117.x

Uroz, S., Ioannidis, P., Lengelle, J., Cébron, A., Morin, E., Buée, M., et al. (2013). Functional assays and metagenomic analyses reveals differences between the microbial communities inhabiting the soil horizons of a Norway spruce plantation. PLOS ONE 8:e55929. doi: 10.1371/journal.pone.0055929

van Heerwaarden, J., Doebley, J., Briggs, W. H., Glaubitz, J. C., Goodman, M. M., Gonzalez, J. D. J. S., et al. (2011). Genetic signals of origin, spread, and introgression in a large sample of maize landraces. Proc. Natl. Acad. Sci. U.S.A. 108, 1088-1092. doi: 10.1073/pnas.1013011108

Wang, Q., Garrity, G. M., Tiedje, J. M., and Cole, J. R. (2007). Naive Bayesian classifier for rapid assignment of rRNA sequences into the new bacterial taxonomy. Appl. Environ. Microb. 73, 5261-5267. doi: 10.1128/AEM.00062-07

Conflict of Interest Statement: The authors declare that the research was conducted in the absence of any commercial or financial relationships that could be construed as a potential conflict of interest.

Copyright (c) 2016 Correa-Galeote, Bedmar, Fernández-González, Fernández-López and Arone. This is an open-access article distributed under the terms of the Creative Commons Attribution License (CC BY). The use, distribution or reproduction in other forums is permitted, provided the original author(s) or licensor are credited and that the original publication in this journal is cited, in accordance with accepted academic practice. No use, distribution or reproduction is permitted which does not comply with these terms. 